\title{
Photodynamic therapy augments the efficacy of oncolytic vaccinia virus against primary and metastatic tumours in mice
}

\author{
M Gil', M Bieniasz' ${ }^{1,5}$, M Seshadri' ${ }^{2}$ D Fisher', MJ Ciesielski ${ }^{3}$, Y Chen ${ }^{4}$, RK Pandey ${ }^{4}$ and D Kozbor, ${ }^{*}$ \\ 'Department of Immunology, Roswell Park Cancer Institute, Buffalo, NY 14263, USA; ${ }^{2}$ Department of Pharmacology and Therapeutics, Roswell Park \\ Cancer Institute, Buffalo, NY 14263, USA; ${ }^{3}$ Department of Neurosurgery, Roswell Park Cancer Institute, Buffalo, NY I 4263, USA; ${ }^{4}$ Department of Cell \\ Stress Biology, Roswell Park Cancer Institute, Buffalo, NY 14263, USA
}

BACKGROUND: Therapies targeted towards the tumour vasculature can be exploited for the purpose of improving the systemic delivery of oncolytic viruses to tumours. Photodynamic therapy (PDT) is a clinically approved treatment for cancer that is known to induce potent effects on tumour vasculature. In this study, we examined the activity of PDT in combination with oncolytic vaccinia virus (OVV) against primary and metastatic tumours in mice.

METHODS: The effect of 2-[I-hexyloxyethyl-]-2-devinyl pyropheophorbide-a (HPPH)-sensitised-PDT on the efficacy of oncolytic virotherapy was investigated against subcutaneously implanted syngeneic murine NXS2 neuroblastoma and human FaDu head and neck squamous cell carcinoma xenografts in nude mice. Treatment efficacy was evaluated by monitoring tumour growth and survival. The effects of combination treatment on vascular function were examined using magnetic resonance imaging (MRI) and immunohistochemistry, whereas viral replication in tumour cells was analysed by a standard plaque assay. Normal tissue phototoxicity following PDT-OV treatment was studied using the mouse foot response assay.

RESULTS: Combination of PDT with OV resulted in inhibition of primary and metastatic tumour growth compared with either monotherapy. PDT-induced vascular disruption resulted in higher intratumoural viral titres compared with the untreated tumours. Five days after delivery of OW, there was a loss of blood flow to the interior of tumour that was associated with infiltration of neutrophils. Administration of OW did not result in any additional photodynamic damage to normal mouse foot tissue.

CONCLUSION: These results provide evidence into the usefulness of PDT as a means of enhancing intratumoural replication and therapeutic efficacy of OV.

British Journal of Cancer (201 I) 1 05, I512-1521. doi:I0.1038/bjc.2011.429 www.bjcancer.com

Published online I| October 201|

(C) 2011 Cancer Research UK

Keywords: photodynamic therapy; oncolytic viruses; tumour vasculature

Oncolytic viruses replicate in and destroy cancer cells selectively (Guo et al, 2008; Kirn and Thorne, 2009). Clinical trials performed over the last decade to evaluate the activity of oncolytic viruses have utilised local (e.g., intratumoural) or regional (e.g., intracavitary or intra-arterial) routes of delivery (Hu et al, 2006; Small et al, 2006; Liu et al, 2008). However, effective treatment of invasive and metastatic cancer is likely to require systemic administration of the virus. Poxviruses are characterised by their ability to travel systemically through the blood (Thorne et al, 2007; Kirn et al, 2008) because the extracellular enveloped vaccinia virus shrouds itself in a host cell-derived envelope that contains several host complement control proteins and few exposed viral proteins making it resistant to neutralisation by complement (Vanderplasschen et al, 1998; Bell et al, 2004). Engineered oncolytic vaccinia viruses (OVVs) have demonstrated promising results in the treatment of cancer in preclinical models and early clinical trials (Park et al, 2008; Kirn and Thorne, 2009),

*Correspondence: Dr D Kozbor;

E-mail: danuta.kozbor@roswellpark.org

${ }^{5}$ Current address: Department of Oncological Sciences, Huntsman Cancer Institute, 2000 Circle of Hope, Salt Lake City, UT 84II 2, USA

Revised I September 201 I; accepted 2I September 201।; published online || October 20 || and systemic virus spread has been demonstrated in patients with widespread metastases (DiPaola et al, 2006; Park et al, 2008). However, the impressive antitumour activity of OVs seen in experimental model systems has not translated into effective 'cures' in patients. This could at least in part be attributed to the presence of a tumour vascular network that acts as a barrier for viral egress into tumours (Breitbach et al, 2007). It was therefore our hypothesis that therapies targeted towards the vasculature can be exploited for the purpose of improving the systemic delivery of OVs to tumours. To test this hypothesis, we investigated the antitumour activity of OVV expressing the enhanced green fluorescence protein (OVV-EGFP) in combination with photodynamic therapy (PDT).

Photodynamic therapy is a clinically approved therapy for solid tumours that is based on the photoactivation of a tumourlocalising agent, the sensitiser, resulting in the generation of cytotoxic singlet oxygen $\left({ }^{1} \mathrm{O}_{2}\right)$ (Pandey et al, 1991). The chlorin-based 2-[1-hexyloxyethyl-]-2-devinyl pyropheophorbide-a $(\mathrm{HPPH})$, is a second-generation sensitiser that exhibits favourable photophysical and pharmacokinetic properties and is currently being investigated in clinical trials (Bellnier et al, 2003). In preclinical studies, HPPH-PDT has been shown to result in varying patterns of vascular, cellular and inflammatory responses, and long-term tumour control rates depending on the treatment 
regimen employed (Henderson et al, 2004; Seshadri et al, 2005). Here, we examined the therapeutic activity of HPPH-sensitised PDT in combination with thymidine kinase (TK)- and vaccinia growth factor (VGF)-deleted vaccinia virus expressing the EGFP as a tracking marker (Gil et al, 2009) against NXS2 neuroblastomas established in syngeneic mice and human $\mathrm{FaDu}$ xenografts established in athymic nude mice. The objectives of the study were to determine whether HPPH-sensitised PDT enhances the antitumour efficacy of OVV and elucidate the potential mechanism of interaction between the two treatments.

\section{MATERIALS AND METHODS}

\section{Cell lines and generation of EGFP expressing rOVV}

The murine GD2 ganglioside ${ }^{+}$, NXS2 neuroblastoma cell line, was provided by Dr RA Reisfeld (The Scripps Research Institute). FaDu head and neck squamous cell carcinoma was provided by Dr YM Rustum (RPCI), and human HuTK-143 fibroblasts were obtained from ATCC (CRL-8303). The OVV-EGFP virus was generated by homologous recombination using VSC20 vaccinia virus and the vaccinia shuttle plasmid pSEL-EGFP (McCart et al, 2001) as described previously (Gil et al, 2009). The VSC20 vaccinia virus with lacZ gene cloned in place of the VGF gene was obtained from Dr B Moss (National Institutes of Health) and the pSEL-EGFP vaccinia shuttle plasmids were obtained from Dr D Bartlett (University of Pittsburgh Cancer Institute). Multiple plaques of the recombinant viruses were isolated in HuTK-143 cells by BrdU selection. After amplification on HeLa cells, the OVV-EGFP virus was purified over the sucrose gradient, titrated, and the expression of EGFP in infected NXS2 and FaDu cells was confirmed by immunofluorescence microscopy.

UV light inactivation of viruses was done as described (Guse et al, 2010). Briefly, viruses were suspended in $10 \mu \mathrm{g} \mathrm{ml}^{-1}$ psoralen in Hanks balanced salt solution containing $0.1 \%$ bovine serum albumin and treated with UV light $(365 \mathrm{~nm})$ for $3 \mathrm{~min}$. A plaque assay was used to confirm lack of viral replication.

\section{In vivo studies}

Female A/J and nu/nu CByJ.Cg-Foxn1nu/J. mice (Jackson Laboratory, Bar Harbor, ME, USA) were inoculated s.c. on the right shoulder with $2 \times 10^{6} \mathrm{NXS} 2$ and $5 \times 10^{6} \mathrm{FaDu}$ cells, respectively. NXS2-bearing mice $(n=10-15)$ were injected i.v. with $10^{8}$ plaqueforming units (PFUs) of OVV-EGFP, whereas in FaDu-challenged mice, the viral dose was reduced to $2.5 \times 10^{7} \mathrm{PFU}$. After 7 days, the FaDu tumour-bearing nude mice received i.p. $100 \mu \mathrm{g}$ of neutralising antibodies (neutralizing titre $1: 100$ ) prepared from sera of vaccinia virus-immunised mice to inhibit disseminated infection associated with acute inflammatory response (Guse et al, 2010). The neutralising antibodies were delivered for an additional 4 days. This treatment prevents the release of extracellular enveloped vaccinia virus from infected cells (Vanderplasschen et al, 1997).

2-[1-Hexyloxyethyl-]-2-devinyl pyropheophorbide-a $(0.45 \mu \mathrm{mol}$ $\mathrm{kg}^{-1}$ ) was injected i.v. and tumours were illuminated with $665-\mathrm{nm}$ wavelength light $24 \mathrm{~h}$ later. The light source consisted of a dye laser (Spectra-Physics, Newport Corporation, Irvine, CA, USA) pumped by an argon ion laser tuned to $665 \mathrm{~nm}$ using DCM dye (Exciton Inc., Dayton, OH, USA). The PDT treatment was delivered using three illumination regimens: $48 \mathrm{~J} \mathrm{~cm}^{-2}$ delivered at $7 \mathrm{~mW} \mathrm{~cm} \mathrm{~cm}^{-2}$, $128 \mathrm{~J} \mathrm{~cm}^{-2}$ at $14 \mathrm{~mW} \mathrm{~cm}^{-2}$ and $135 \mathrm{~J} \mathrm{~cm}^{-2}$ at $75 \mathrm{~mW} \mathrm{~cm}^{-2}$. For combination studies, OVV-EGFP was injected i.v. $12 \mathrm{~h}$ after PDT. Tumour-bearing mice treated with HPPH or OV served as controls. Tumour growth was monitored by measuring s.c. tumours once to three times a week with a microcaliper until they reached a volume $1700 \mathrm{~mm}^{3}$, at which time the mice were euthanised. Tumour volume, $V$, was calculated with the formula
$V=\left(\mathrm{lw}^{2} / 2\right)$, where $l$ is the longest axis of the tumour and $w$ is the axis perpendicular to $l$. Log-transformation was applied to $V$ for purpose of statistical analysis. For the therapy of metastatic disease, NXS2-bearing mice $(n=6)$ underwent PDT and/or OV, and tumours $\left(V=\sim 200 \mathrm{~mm}^{3}\right)$ were excised 7 days later. Control mice had the primary tumour excised without PDT/OVV-EGFP treatment. Survival was defined as the point at which mice were euthanised because of extensive tumour burden. All experimental procedures were approved by the Institutional Animal Care and Use Committee at the RPCI.

\section{Mouse foot response assay}

The mouse foot response assay was performed on non-tumourbearing $\mathrm{A} / \mathrm{J}$ mice to assess normal tissue phototoxicity in vivo as described previously (Pandey et al, 1991). Briefly, НРPH $\left(0.45 \mu \mathrm{mol} \mathrm{kg}^{-1}\right)$ was administered i.v. alone or in combination with OVV-EGFP $\left(10^{8} \mathrm{PFU}\right.$, injected 12 -h post PDT). The mice were divided into four groups (three mice per group) to analyse skin phototoxicity after exposure to light (similar to PDT conditions) produced by the solar simulator (Model 6137, ORIEL Co., Irvine, CA, USA) (Pandey et al, 1991). One of the hind feet of each mouse in the first group was exposed to light (at the therapeutic dose) at $24 \mathrm{~h}$ post HPPH injection. The subsequent groups were exposed at 48,72 and $96 \mathrm{~h}$, respectively. In each group, the unexposed hind feet served as controls. Foot response was judged using a 0-3 scale: $0-0.1=$ no apparent difference from normal, $0.3=$ slight oedema, $0.5=$ moderate oedema, $0.75=$ large oedema, $1.0=$ large erythema with exudate, $1.2=$ moderate oedema with slightly crusty appearance, $1.5=$ definite erythema, $1.65=$ slightly damaged and/or slight fusion of toes; $2.0=$ most toes are fused but no change in general shape. Response $>2.0$ indicates unacceptably severe normal tissue reaction (Pandey et al, 1991).

\section{Immunohistochemical and flow cytometry analyses}

Paraffin sections (4- $\mu$ m-thick) of tumours were stained by a routine immunohistochemical method using a rat $\mathrm{mAb}$ specific for CD31 (clone MEC 13.3; Pharmingen, San Diego, CA, USA) at 1:30 dilution in PBS for $60 \mathrm{~min}$ at room temperature, followed by biotinylated goat anti-rat IgG (Pharmingen) at $1: 100$ dilution for 30 min, streptavidin-peroxidase (50-242; Zymed, San Francisco, CA, USA) for $30 \mathrm{~min}$, and diaminobenzidine for $5 \mathrm{~min}$.

Numbers of neutrophils/MDSCs in NXS2 tumours and the peripheral blood in tumour-bearing mice were determined by staining with PE- and PECy7-conjugated mAbs to Gr1 and CD11b (BD Pharmingen, San Diego, CA, USA), respectively. Before specific Ab staining, cells were incubated with Fc blocker (anti$\mathrm{CD} 16 / \mathrm{CD} 32 \mathrm{mAb}$ ) for $10 \mathrm{~min}$. Background staining was assessed using isotype controls. All flow cytometric evaluations were performed on a FACScan flow cytometer (Becton Dickinson, Franklin Lakes, NY, USA).

\section{Characterisation of reported gene expression and viral replication}

FaDu cells were incubated with or without $0.8 \mu$ m. 2-[1-Hexyloxyethyl-]-2-devinyl pyropheophorbide-a for $24 \mathrm{~h}$ before light treatment and infection with OVV-EGFP at multiplicity of infection (MOI) of 5 PFU per cell. Expression of EGFP was determined $16 \mathrm{~h}$ after the treatment by flow cytometry. The viral titres were determined by a plaque assay $72 \mathrm{~h}$ later. To quantify intratumoural load of OVV, tumours were resected 5 days after the OV and PDT treatments, homogenised and analysed by a plaque assay.

\section{Analysis of tumour perfusion}

Tumour-bearing mice were injected intravenously with $100 \mu \mathrm{l}$ of a $50 \%$ solution of $100 \mathrm{~nm}$ diameter orange fluorescent microspheres 
(Molecular Probes, Carlsbad, CA, USA). After $5 \mathrm{~min}$, animals were euthanised and the tumours were immediately snap frozen as previously described (Breitbach et al, 2007). Tumour perfusion was analysed by visualising fluorescent microspheres in the vasculature of fixed sections using a Zeiss Axiophot HRM Inverted fluorescent microscope (Zeiss Inc., Jena, Germany) and analysed using Image-Pro 6.2 software (Media Cybernetics Inc., Silver Spring, MD, USA).

\section{Magnetic resonance imaging}

Experimental magnetic resonance imaging (MRI) examinations were performed using a $4.7 \mathrm{~T} / 33-\mathrm{cm}$ horizontal bore magnet (GE NMR Instruments, Fremont, CA, USA) incorporating AVANCE digital electronics (Bruker Biospec, Paravision 3.0.2, Bruker Medical, Billerica, MA, USA). Blood volume and permeability measurements were estimated from T1-weighted contrastenhanced MRI (CE-MRI) acquisitions performed using the intravascular contrast agent, albumin-GdDTPA (Contrast Media Laboratory, University of California, San Francisco, CA, USA), as described previously (Seshadri et al, 2008). The agent contains 35 GdDTPA molecules $(94.3 \mathrm{~mm})$ that were bound to each human serum albumin $(2.69 \mathrm{~mm})$. Anatomic coverage included the tumour, kidneys, vena cava and murine muscle tissue. A series of three preliminary noncontrast enhanced images, with repetition times (TR) ranging from 360 to $6000 \mathrm{~ms}$, was acquired before an intravenous bolus injection of the contrast agent for the determination of regional precontrast $\mathrm{T} 1$ relaxation values. Following these baseline acquisitions, albumin-GdDTPA $\left(0.1 \mathrm{mmol} \mathrm{kg} \mathrm{kg}^{-1}\right)$ was administered through tail vein injection, and a second series of five postcontrast images was serially obtained for $\sim 45 \mathrm{~min}$ (day 1). T1 relaxation rates were determined using a saturation recovery, fast spin echo sequence with an effective echo time (TE) of $10 \mathrm{~ms}$, and a TR ranging from 360 to $6000 \mathrm{~ms} \quad(\mathrm{FOV}=32 \times 32 \mathrm{~mm}$, slice thickness $=1.0 \mathrm{~mm}$, matrix size $=128 \times 96$ pixels, number of excitations $(\mathrm{NEX})=3$ ). Following image acquisition, animals were treated with PDT and $12 \mathrm{~h}$ later, the imaging protocol was repeated. Raw image sets were transferred to a processing workstation and converted into Analyze format (Analyze 7.0, Analyze Direct, Overland Park, KS, USA). Blood volume and permeability maps were calculated on a pixel-by-pixel basis using MATLAB (Mathworks Inc., Natick, MA, USA).

\section{Statistical analysis}

The statistical significance of the difference between groups was performed using the two-tailed Student's $t$-test assuming equal variance. Mixed model analysis of variance was used to compare viral titres in tumours treated with virotherapy or PDT and virotherapy. $P<0.05$ was considered statistically significant. The $P$-values for the pairwise group comparisons for the average tumour growth were computed using a repeated measure ANOVA. Kaplan-Meier survival plots were prepared and median survival times were determined for tumour-challenged groups of mice. Statistical differences in the survival across groups were assessed using the log rank Mantel-Cox method. Data were presented as arithmetic mean \pm s.d., and analysed using JMP (SAS Institute Inc., Cary, NC, USA) on a Windows-based platform.

\section{RESULTS}

\section{PDT in combination with OV inhibits primary tumour growth}

Two groups of NXS2-bearing A/J mice with tumour volumes ranging from 100 to $200 \mathrm{~mm}^{3}$ and 200 to $300 \mathrm{~mm}^{3}$ were subjected to treatments with PDT using three different illumination regimens determined by fluence and fluence rates: $48 \mathrm{~J} \mathrm{~cm}^{-2}$ delivered at $7 \mathrm{~mW} \mathrm{~cm}^{-2}, 128 \mathrm{~J} \mathrm{~cm}^{-2}$ at $14 \mathrm{~mW} \mathrm{~cm}^{-2}$ and $135 \mathrm{~J} \mathrm{~cm}^{-2}$ at
$75 \mathrm{~mW} \mathrm{~cm}^{-2}$ (Figures $1 \mathrm{~A}$ and $\mathrm{C}$ ) alone or in combination with OVV-EGFP (Figures $1 \mathrm{~B}$ and D). The virus was injected i.v. $12 \mathrm{~h}$ after PDT since delivery of the virus before PDT treatment led to viral inactivation (data not shown). Additional groups of tumourbearing mice that were treated with $\mathrm{HPPH}$ sensitiser without illumination or OVV-EGFP virus alone served as controls. As shown in Figures 1A and C, PDT using the high fluence/low fluence rate regimen $\left(128 \mathrm{~J} \mathrm{~cm}^{-2}, 14 \mathrm{~mW} \mathrm{~cm}^{-2}\right)$ exhibited the highest antitumour efficacy in both groups of mice and delayed progressive growth of the tumour already 2 weeks after the treatment $(P<0.01)$. The other PDT regimens consisting of a low fluence $48 \mathrm{~J} \mathrm{~cm}^{-2}$ delivered at $7 \mathrm{~mW} \mathrm{~cm}^{-2}$ fluence rate and a high fluence $135 \mathrm{~J} \mathrm{~cm}^{-2}$ delivered at $75 \mathrm{~mW} \mathrm{~cm}^{-2}$ fluence rate were less effective in inhibiting tumour growth. Tumour-free mice were not detected in any of the PDT-treated groups.

Similar to the antitumour effects of PDT treatments, systemic administration of OVV-EGFP only delayed tumour progression compared with control mice (Figures $1 \mathrm{~A}-\mathrm{D} ; P=0.021$ ). In contrast, $50 \%$ (5 out of 10 ) of mice with small tumours $\left(V=100-200 \mathrm{~mm}^{3}\right)$ treated with the combination of PDT $\left(128 \mathrm{~J} \mathrm{~cm}^{-2}\right.$ at $\left.14 \mathrm{~mW} \mathrm{~cm}^{-2}\right)$ and $\mathrm{OV}$ showed complete and durable tumour regression (Figure $1 \mathrm{~B}$, denoted as combo $2 ; P<0.001$ ). This combination treatment also inhibited growth of larger tumours $\left(V=200-300 \mathrm{~mm}^{3}\right)$, although complete tumour eradication was only observed in $20 \%$ of animals (Figure 1D). Other illumination regimens $\left(48 \mathrm{~J} \mathrm{~cm}^{-2}\right.$ delivered at $7 \mathrm{~mW} \mathrm{~cm}^{-2}$ and $135 \mathrm{~J} \mathrm{~cm}^{-2}$ at $75 \mathrm{~mW} \mathrm{~cm}^{-2}$ ) used alone (Figures $1 \mathrm{~A}$ and $\mathrm{C}$ ) or in combination with OVV-EGFP (Figures $1 \mathrm{~B}$ and D; denoted as combos 1 and 3, respectively) also exhibited higher antitumour effects compared with the respective monotherapy treatments but were less effective than the combination of the optimally curative PDT regimen $\left(128 \mathrm{~J} \mathrm{~cm}^{-2}, 14 \mathrm{~mW} \mathrm{~cm}^{-2}\right)$ and $\mathrm{OV}$.

We then investigated whether PDT treatment $\left(128 \mathrm{~J} \mathrm{~cm}^{-2}\right.$ delivered at $14 \mathrm{~mW} \mathrm{~cm}^{-2}$ ) enhances the antitumour efficacy of OVV-EGFP treatment against human xenografts in athymic nude mice. For these studies, human FaDu cell carcinoma xenografts were utilised since multi-institutional phase II-III clinical trials evaluating PDT of head and neck tumours have demonstrated the efficacy of this minimally invasive therapy against early oropharyngeal primary and recurrent cancers (Biel, 2006). In the initial experiments, nude mice with s.c. $\mathrm{FaDu}$ tumours $\left(V=220 \pm 45 \mathrm{~mm}^{3}\right.$ ) were treated with single therapy and analysed for inhibition of tumour growth. Figure 2A shows that PDT $\left(128 \mathrm{~J} \mathrm{~cm}^{-2}\right.$ at $\left.14 \mathrm{~mW} \mathrm{~cm}^{-2}\right)$ monotherapy resulted in $60 \%$ tumour-free survival $(P=0.002)$, whereas treatment with $\mathrm{OV}$ caused $25 \%$ tumour-free animals $(P=0.005)$. On the other hand, the combined $128 \mathrm{~J} \mathrm{~cm}^{-2}$ at $14 \mathrm{~mW} \mathrm{~cm}^{-2}$ and $\mathrm{OV}$ treatments increased the survival rate to $92 \%(P<0.001)$, and was most effective when the virus was delivered $12 \mathrm{~h}$ after PDT (Figure $2 \mathrm{~B}$ ). Administration of the virus 4 or $24 \mathrm{~h}$ after PDT resulted in $<80 \%$ tumour-free survival, whereas delivery of the virus immediately after the illumination regimen was not beneficial (Figure 2B). To determine the effect of different illumination regimens on survival rates of $\mathrm{FaDu}$, we performed additional experiments using $48 \mathrm{~J} \mathrm{~cm}^{-2}$ at $7 \mathrm{~mW} \mathrm{~cm}^{-2}$ or $135 \mathrm{~J} \mathrm{~cm}^{-2}$ at $75 \mathrm{~mW} \mathrm{~cm}^{-2}$ followed by OVV-EGFP delivered $12 \mathrm{~h}$ later. Consistent with the results obtained using NXS2 tumour, PDT treatments consisting of a low fluence $48 \mathrm{~J} \mathrm{~cm}^{-2}$ delivered at $7 \mathrm{~mW} \mathrm{~cm}^{-2}$ fluence rate and a high fluence $135 \mathrm{~J} \mathrm{~cm}^{-2}$ delivered at $75 \mathrm{~mW} \mathrm{~cm}^{-2}$ fluence rate used in combination with OVV were less effective, resulting in $60 \%$ and $40 \%$ tumour-free survival rates, respectively (Figure 2C).

\section{Contrast enhanced-MRI of tumour perfusion after PDT reveals vascular disruption at the time of virus administration}

To investigate the potential mechanisms of interaction between PDT and oncolytic virotherapy, we examined the effect of the PDT 
NXS2 tumour size $100-200 \mathrm{~mm}^{3}$

A

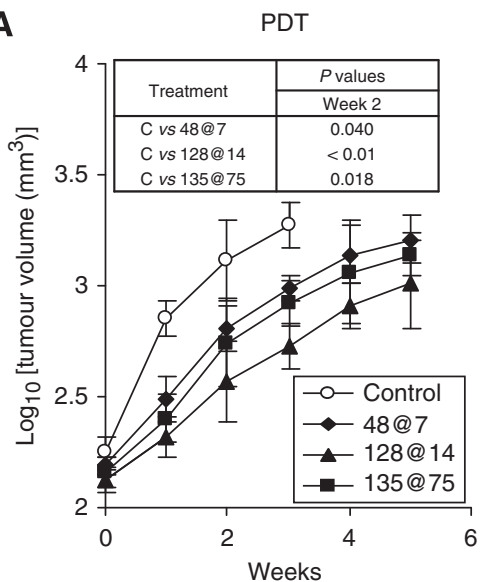

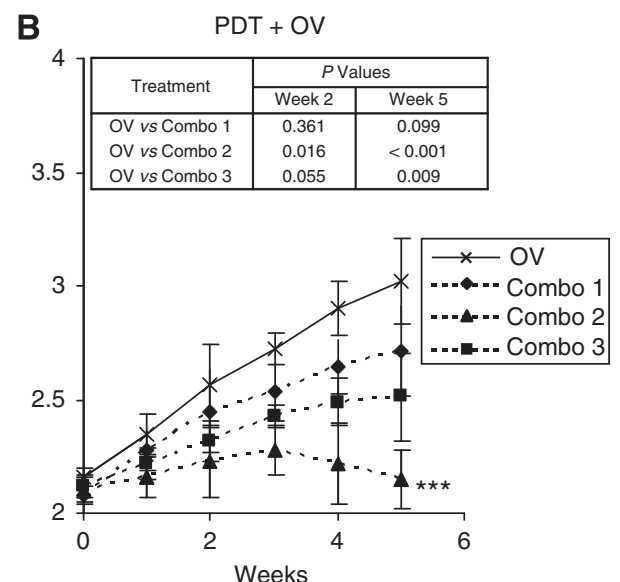

NXS2 tumour size $200-300 \mathrm{~mm}^{3}$
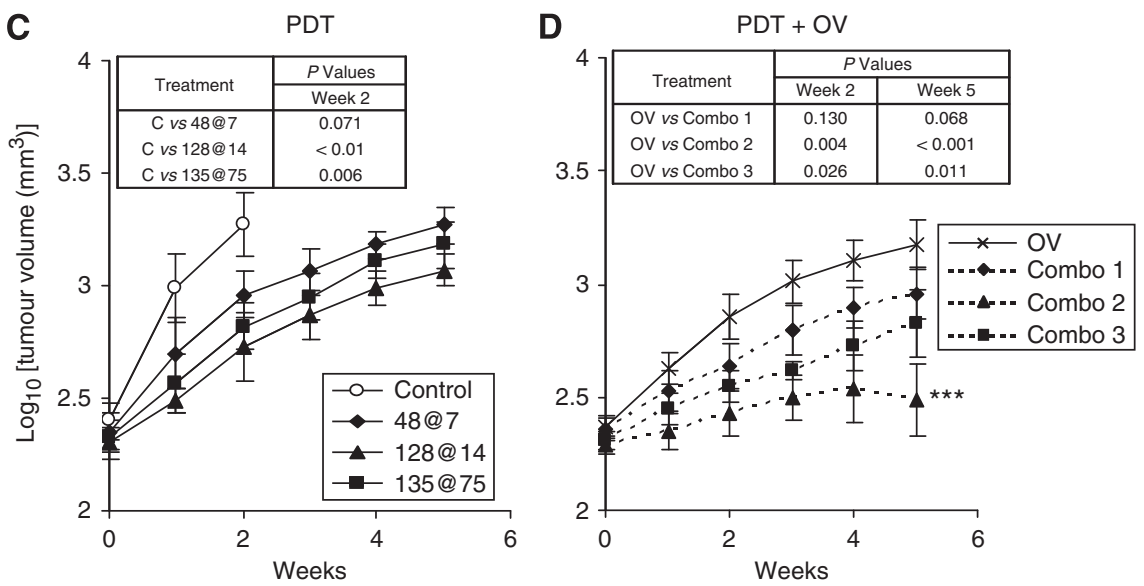

Figure I Inhibition of primary NXS2 tumours with PDT and OVV-EGFP. Tumour-bearing mice $(n=10-15)$ were enrolled when tumour size was $100-200 \mathrm{~mm}^{3}$ or 200-300 $\mathrm{mm}^{3}$ and randomised into two groups. (A and C) Mice were treated with HPPH-PDT of 48 $\mathrm{cm}^{-2} \mathrm{at}_{7} \mathrm{~W} \mathrm{~cm} \mathrm{~cm}^{-2}, 128 \mathrm{~J} \mathrm{~cm} \mathrm{~cm}^{-2}$ at $14 \mathrm{~mW} \mathrm{~cm}^{-2}$ and $135 \mathrm{~J} \mathrm{~cm}^{-2}$ at $75 \mathrm{~mW} \mathrm{~cm}^{-2}$. Control animals received HPPH. (B and D) $10^{8} \mathrm{PFU}$ of OVV-EGFP was delivered i.v. alone or $12 \mathrm{~h}$ after PDT. Data were plotted in log scale as mean \pm s.d., over treatment time. The $P$-values for the pairwise group comparisons for the average tumour growth were computed using ANOVA (**** $<0.00 \mathrm{I}$ ). Combo I, denotes combination of PDT (48 $\mathrm{cm}^{-2}$ at $7 \mathrm{~W} \mathrm{~cm}^{-2}$ ) and OV; combo 2, denotes combination of PDT $\left(128 \mathrm{~J} \mathrm{~cm}^{-2}\right.$ at $\left.14 \mathrm{~mW} \mathrm{~cm}^{-2}\right)$ and OV; and combo 3, denotes combination of PDT $\left(135 \mathrm{~J} \mathrm{~cm}^{-2}\right.$ at $\left.75 \mathrm{~mW} \mathrm{~cm}^{-2}\right)$ and OV.

regimen on tumour vascular function at the time of OVV-EGFP delivery. Non-invasive CE-MRI with albumin-GdDTPA was performed to assess the vascular response of $\mathrm{FaDu}$ $\left(V=100.8 \pm 30.8 \mathrm{~mm}^{3}\right)$ to PDT $\left(128 \mathrm{~J} \mathrm{~cm}^{-2}\right.$ at $\left.14 \mathrm{~mW} \mathrm{~cm}^{-2}\right) 12 \mathrm{~h}$ after the treatment. Concentration of a contrast agent within the tumour was estimated by measuring the change in T1-relaxation rate $(\Delta R 1)$ in the tumour. Individual $R 1$ maps $(R=1 / T 1)$ along with blood volume and permeability maps were generated on a pixel-by-pixel basis at baseline and post-treatment time points. As shown in Figure 3A, FaDu tumours (bounding box) exhibited regions of high blood volume before PDT (pre-PDT) indicating the presence of a functioning tumour vascular network. A spatially heterogenous distribution of regions with enhanced permeability was also observed. At 12-h post PDT, tumours were characterised by central regions of low blood volume along with markedly hyper-permeable regions in the tumour periphery (Figure $3 \mathrm{~A}$, overlay). Consistent with this observation, the change in T1-relaxation $(\Delta \mathrm{R} 1)$ values calculated from regions-of-interest placed in the tumour centre showed a statistically significant $(P<0.05)$ reduction 12 -h post PDT $(0.027 \pm 0.01)$ compared with baseline $(0.369 \pm 0.06)$. In contrast, estimates of contrast agent concentration in the peripheral regions of the tumours did not reveal significant differences between baseline $(0.316 \pm 0.05)$ and post-treatment $(0.287 \pm 0.10)$ time points. The OVV had no effect on tumour vasculature during the first $12 \mathrm{~h}$ following the virus delivery (not shown).

\section{PDT enhances intratumoural viral titres}

The results of CE-MRI performed $12 \mathrm{~h}$ after PDT treatment suggested that blood vessels in tumour periphery that survived the illumination regimen of $128 \mathrm{~J} \mathrm{~cm}^{-2}$ at $14 \mathrm{~mW} \mathrm{~cm}^{-2}$ could serve as effective conduits for delivery and spread of OVV-EGFP within the tumour microenvironment. To assess the effect of the optimally curative PDT treatment on intratumoural viral loads and compare it with that of other illumination regimens $\left(48 \mathrm{~J} \mathrm{~cm}^{-2}\right.$ at $7 \mathrm{~mW} \mathrm{~cm} \mathrm{~cm}^{-2}$ and $135 \mathrm{~J} \mathrm{~cm}^{-2}$ at $75 \mathrm{~mW} \mathrm{~cm}^{-2}$ ), tumours were resected 5 days after the treatment and viral titres were quantified by a standard plaque assay. For the analysis, we used the FaDu tumour model system, which is highly susceptible to OVV-EGFP infection. Figure $3 \mathrm{~B}$ revealed over 10 -fold higher viral titres recovered from tumours after the combined $128 \mathrm{~J} \mathrm{~cm}^{-2}$ at $14 \mathrm{~mW} \mathrm{~cm}^{-2}$ and $\mathrm{OV}$ treatment compared with control tumours $(P=0.004)$. Only small increases in viral titres were measured in tumours treated with 
A FaDu (128@14 PDT or OV)

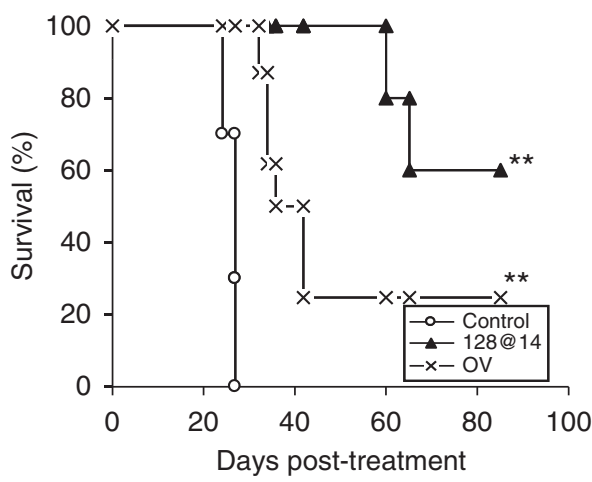

B FaDu (128@14PDT and OV)

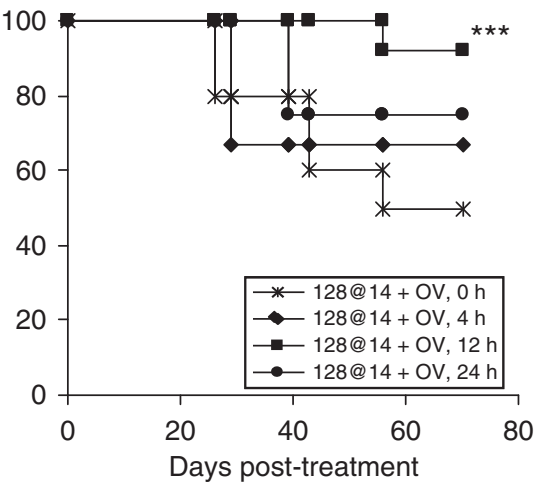

C

FaDu (PDT and OV)

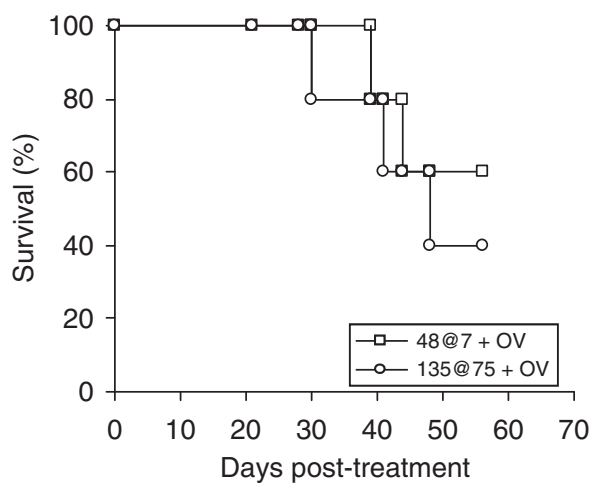

Figure 2 Therapeutic benefits of combination therapy against FaDu xenografts in nude mice. (A) Nude mice with s.c. FaDu tumours $(n=10-15$; $\left.V=220 \pm 45 \mathrm{~mm}^{3}\right)$ were injected with OVV-EGFP $\left(2.5 \times 10^{7}\right.$ PFU) or treated with PDT $\left(128 \mathrm{~J} \mathrm{~cm} \mathrm{~cm}^{-2} \mathrm{at} \mathrm{mW} \mathrm{cm}^{-2}\right)$. Control mice received $\mathrm{HPPH}$. (B) FaDu-bearing mice were treated with PDT, and OVV-EGFP was delivered at time 0 or 4,12 or $24 \mathrm{~h}$ after PDT. (C) FaDu-bearing mice were treated with $48 \mathrm{~J} \mathrm{~cm}^{-2}$ at $7 \mathrm{~W} \mathrm{~cm} \mathrm{~cm}^{-2}$ or $135 \mathrm{~J} \mathrm{~cm}^{-2}$ at $75 \mathrm{~mW} \mathrm{~cm}^{-2}$ regimen followed by $\mathrm{OVV}$-EGFP delivered $\mathrm{I} 2 \mathrm{~h}$ later. $* * P<0.0 \mathrm{I}$, $* * * P<0.00 \mathrm{I}$.

PDT regimens of $135 \mathrm{~J} \mathrm{~cm}^{-2}$ at $75 \mathrm{~mW} \mathrm{~cm}^{-2}$ and $48 \mathrm{~J} \mathrm{~cm}^{-2}$ at $7 \mathrm{~mW} \mathrm{~cm}^{-2}$. The differences in intratumoural viral titres after PDT treatments were also reflected in numbers of $\mathrm{EGFP}^{+}$cells measured by imaging cytometry on single cell suspensions (Figure 3C). The analyses revealed significantly higher numbers of OVV-EGFP-infected cells after treatment with the $128 \mathrm{~J} \mathrm{~cm}^{-2}$ at $14 \mathrm{~mW} \mathrm{~cm}^{-2}$ illumination regimen compared with the untreated controls $(68.0 \pm 15 \%$ vs $12.0 \pm 5.3 \%$, respectively; $P<0.001)$. It is noteworthy that EGFP expression in FaDu tumours after PDT of $128 \mathrm{~J} \mathrm{~cm}^{-2}$ at $14 \mathrm{~mW} \mathrm{~cm}^{-2}$ was elevated compared with the untreated counterparts although the differences did not reach statistical significance $(57793 \pm 7654$ and $51086 \pm 3443$, respectively; $P=0.07)$. This could reflect an effect of PDT-induced inflammatory responses characterised by low levels of IL-6 cytokine and MIP-1 and MIP-2 chemokine expression (Henderson et al, 2004), and was consistent with an enhanced activity of the synthetic early/late viral promoter stimulated by factors activated or released from tumour after PDT treatment (Kick et al, 1995; Wild et al, 2005; Mitra et al, 2006). However, it is also possible that the HPPH sensitiser could affect the viral promoter activity and/or viral replication in tumour cells.

\section{Tumour cells after PDT treatment are susceptible to OVV-EGFP infection}

We next investigated the effect of the optimally curative PDT regimen on the activity of the synthetic early/late promoter and viral replication in vitro. FaDu cells were cultured for $24 \mathrm{~h}$ in the presence or absence of HPPH before infection with OVV-EGFP
(MOI of 5 PFU per cells). Tumour cells that were treated with light (identical to the PDT condition) or PDT were also included in the study. The expression of EGFP determined $16 \mathrm{~h}$ after the viral infection by a flow cytometry analysis revealed that HPPH or light treatment applied separately had small effects on the synthetic early/late promoter activity (Figure 4A). Similarly, no changes in viral titres were detected in cell cultures $72 \mathrm{~h}$ after the treatment (Figure 4B). On the other hand, PDT-treated FaDu cells exhibited profound decreases in the promoter activity $(P=0.008)$ as well as viral replication $(P=0.011)$, although the cells were capable of generating a replication competent virus.

\section{OV treatment does not increase normal tissue phototoxicity}

The effects of OV treatment on normal tissue phototoxicity was examined using the mouse foot response assay. As shown in Figure 4C, injection of OVV to HPPH-treated mice did not result in any additional damage to normal mouse foot tissue after exposure to light (Figure 4C). Only a moderate degree of oedema (score: 0.7) was observed in both HPPH and HPPH-OV-treated mice on day 1 at 24 -h post injection of HPPH. Resolution of normal tissue damage was observed within 3 days of treatment.

\section{Vascular collapse in tumours after PDT and OVV treatments}

Previous studies have shown that oncolytic vesicular stomatitis virus (VSV) and OVV cause vascular collapse within tumours $24 \mathrm{~h}$ 
A
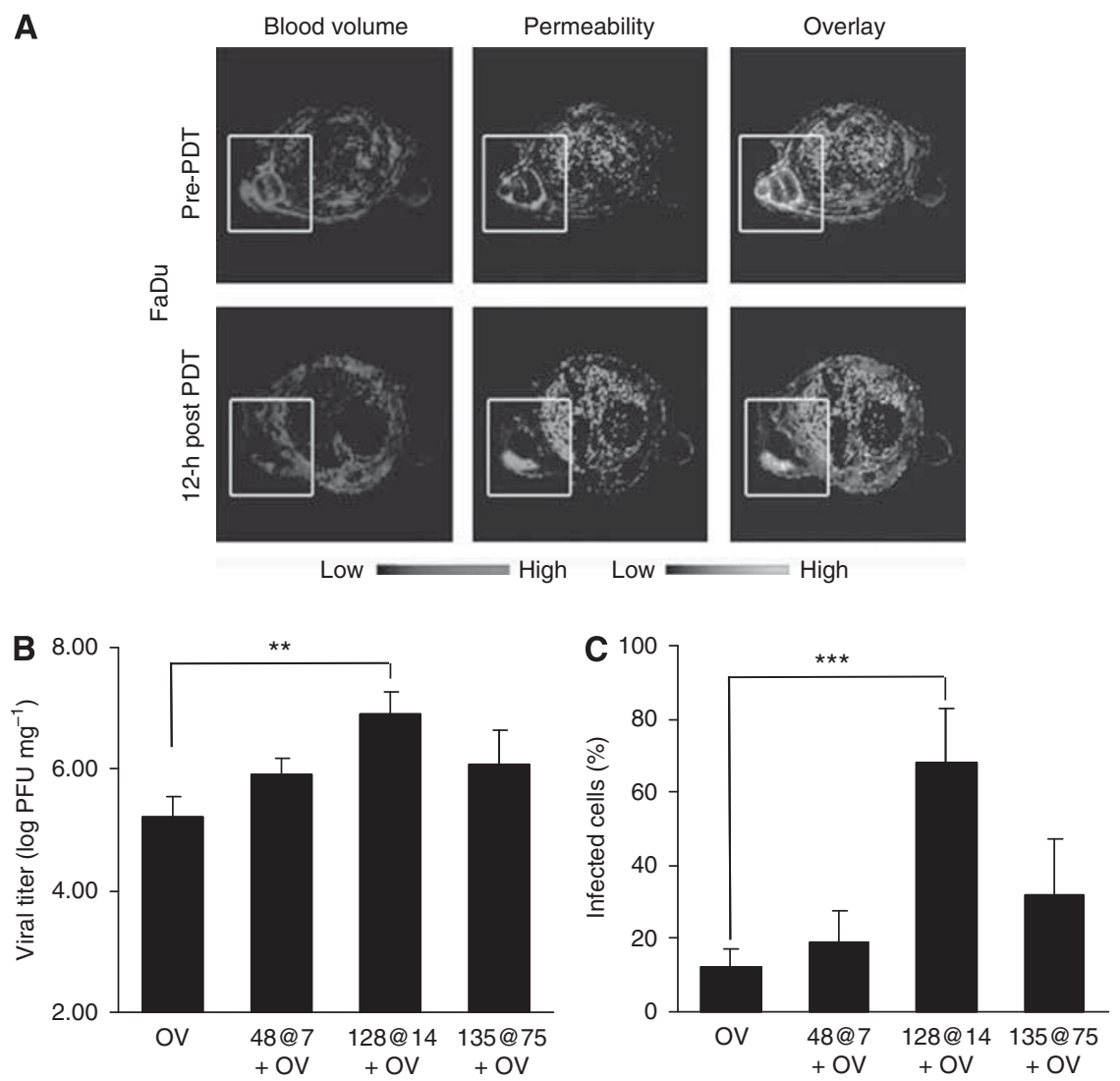

Figure 3 Photodynamic therapy-induced vascular disruption augments intratumoural viral replication. (A) Blood volume and permeability maps of mice with FaDu tumours $(n=3)$ before and $12 \mathrm{~h}$ after PDT $\left(128 \mathrm{~J} \mathrm{~cm}{ }^{-2}\right.$ at $14 \mathrm{~mW} \mathrm{~cm}^{-2}$ ). Blood volume (pseudo-colourized in red) and permeability (pseudocolourized in green) maps were calculated from serial TI-weighted MR acquisitions performed before and after administration of albumin-GdDTPA. Representative maps of a mouse bearing FaDu tumour (bounding box) are presented. (B) Intratumoural replication of OVV-EGFP in FaDu tumours. Nude mice $(n=3)$ bearing FaDu tumours $\left(200-300 \mathrm{~mm}^{3}\right)$ were injected i.v. with OVV-EGFP $\left(2.5 \times 10^{7}\right.$ PFU). In some animals, the virus was delivered I $2 \mathrm{~h}$ after the indicated PDT regimens. After 5 days, tumours were resected, homogenised, and a standard plaque assay was performed. The vaccinia titres are presented as the mean $\log _{10} \pm \mathrm{s}$.d. (error bars) of PFU per $\mathrm{mg}$ total protein of tumour tissues. ${ }^{*} * P<0.01$. (C) The numbers of EGFP ${ }^{+}$tumour cells in the same groups of mice were determined by multispectral image cytometry. Data are presented as arithmetic mean \pm s.d. of three independent experiments. $* * * P<0.001$. The colour reproduction of this figure is available at the British Journal of Cancer online.

and 5 days after the respective infection (Breitbach et al, 2007, 2011). These findings raise a possibility that PDT-mediated vascular destabilisation at the time of viral injection could be further potentiated by OVV-EGFP. Therefore, we analysed changes in tumour perfusion in a highly metastatic NXS2 tumour model 5 days after the mono- and combined-therapy treatments. In order to visualise perfusion, $100 \mathrm{~nm}$ fluorescence beads (microspheres) were injected i.v. to tumour-bearing mice $5 \mathrm{~min}$ before tumour resection as described (Breitbach et al, 2007, 2011). Tumour sections were prepared and analysed under fluorescence microscopy. Figure 5A reveals a relatively uniform distribution of fluorescence beads in the control tumours. The beads were accumulated in the periphery of tumours treated with OVV-EGFP or PDT monotherapy, and were detectable only in the tumour rim after the combined treatment. The results of tumour perfusion studies were consistent with immunohistochemical analyses of tumour tissues stained with $\mathrm{mAb}$ directed to $\mathrm{CD} 31$ to visualise blood vessels. Figure $5 \mathrm{~B}$ shows that in tumour sections from control mice, vascular endothelial cells were uniformly distributed throughout the tumour. In contrast, tumours from mice treated with the virus had substantially fewer blood vessels and these were almost exclusively found in the tumour periphery. Following PDT, vessels were largely disrupted, although few morphologically intact endothelial cells could be identified consistent with the previous findings (Henderson et al, 2004). After the combined PDT/OV treatment, the viable vessels could not be accurately discerned as they were largely necrotic both in the periphery and core of the tumour.

\section{Enhanced recruitment of neutrophils to tumours after treatment with OV alone or in combination with PDT}

It has been demonstrated that neutrophils are one of the first cell type recruited to the sites of infections (Nathan, 2006), and have been implicated in virus-induced loss of tumour perfusion by clogging of small capillaries (Breitbach et al, 2011). On the basis of these findings, and because $\mathrm{Gr} 1^{+} \mathrm{CD} 11 \mathrm{~b}^{+}$neutrophils/myeloidderived suppressor cells (MDSCs) have recently been involved in regulating organ-specific tumour spread (Yan et al, 2010), we investigated whether changes in tumour vasculature after PDT and/or OV treatment would affect accumulation of neutrophils/ MDSCs in tumours and the peripheral blood of NXS2 tumourbearing mice. A double staining with Gr1- and CD11b-specific mAbs followed by a flow cytometry analysis was carried out on single cell suspensions prepared from tumours resected 5 days after the treatment. A parallel analysis was performed on peripheral blood collected from tumour-bearing mice at the time of tumour resection. As shown in Figure 6A, there was approximately two-fold higher accumulation of $\mathrm{Gr}^{+} \mathrm{CD}^{+} 1 \mathrm{~b}^{+}$ cells in the OVV-treated tumours $(P=0.005)$. The increased 

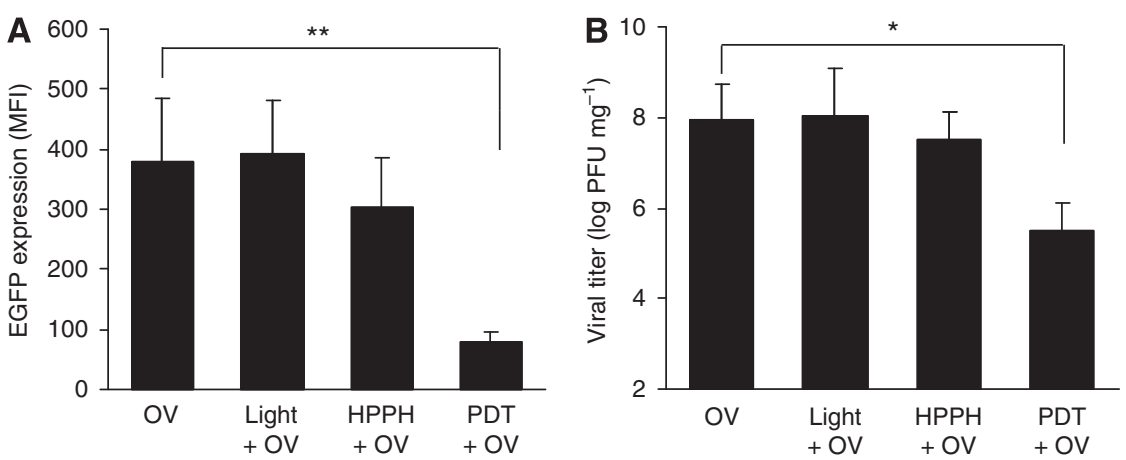

C

Skin phototoxicity

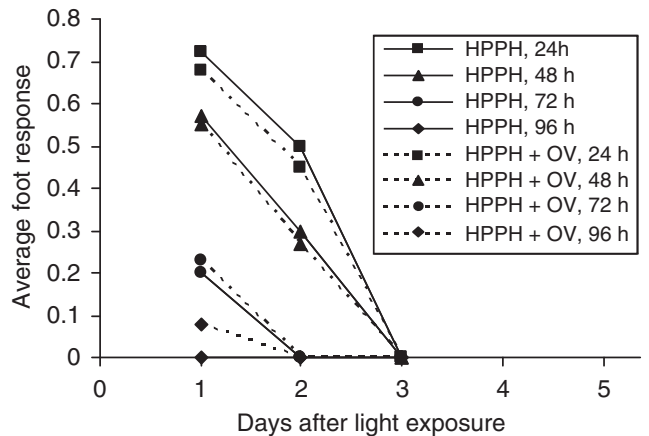

Figure 4 The effect of PDT on activity of the synthetic early/late promoter, viral replication, and normal tissue phototoxicity. (A) FaDu cells were incubated with or without HPPH for $24 \mathrm{~h}$ before light treatment and infection with OVV-EGFP (MOI of 5 PFU per cell). The level of EGFP expression was determined $16 \mathrm{~h}$ after the treatment by flow cytometry. (B) The virus was quantified after $72 \mathrm{~h}$ after infection by plaque titration. The OV titres are presented as the mean $\log _{10} \pm$ s.d. (error bars) of PFU per millilitre. ( $* P<0.05$, $* * P<0.01$ ). (C) Mouse foot response assay. Non-tumour-bearing mice were injected with HPPH $\left(0.45 \mu \mathrm{mol} \mathrm{kg}{ }^{-1}\right.$, i.v.) alone or in combination with OVV-EGFP ( $10^{8}$ PFU, administered $12 \mathrm{~h}$ after PDT). The mice were divided into four groups (three mice per group) to analyse skin phototoxicity by exposing the hind foot to light. The first group was exposed after 24-h post HPPH injection and other groups at 48,72 and $96 \mathrm{~h}$ postinjection, respectively. In each group, the unexposed hind feet served as controls.

accumulation of the inflammatory cells in tumours coincided their reduction in the peripheral blood (Figure 6A; $P=0.008$ ). Similar distributions of neutrophils/MDSC in tumours and blood were observed in tumour-bearing mice after PDT and OV treatments (Figure $6 \mathrm{~A} ; P<0.05)$. Altogether, these findings support the previous observation that the vascular changes mediated by OVs within the tumour may act as a sink for activated neutrophils (Breitbach et al, 2007, 2011). Consistent with the report that minimal numbers of tumour infiltrating $\mathrm{Gr} 1^{+} \mathrm{CD} 11 \mathrm{~b}^{+}$cells were detected using the optimally curative PDT regimen (Henderson et al, 2004), accumulation of inflammatory neutrophils in tumours and the peripheral blood after PDT treatment $128 \mathrm{~J} \mathrm{~cm}^{2}$ at $14 \mathrm{~mW} \mathrm{~cm}^{-2}$ did not differ from controls (Figure 6A).

\section{Inhibition of metastatic disease by a combined PDT and OV therapy}

The ability of NXS2 neuroblastoma to develop spontaneous metastasis after excision of the primary tumour (Neal et al, 2004) provided a model for investigating whether the tumour vascular shutdown and infiltration of neutrophils induced by OVV-EGFP alone or in combination with PDT $\left(128 \mathrm{~J} \mathrm{~cm}^{-2}\right.$, $14 \mathrm{~mW} \mathrm{~cm}^{-2}$ ) affect the kinetics of metastatic disease. A/J mice bearing established s.c. NXS2 tumours $\left(V=\sim 200 \mathrm{~mm}^{3}\right)$ underwent single or combined treatment and tumours were excised 7 days later. Control mice had the primary tumour excised without treatment. As shown in Figure 6B, untreated mice succumbed to metastatic disease within $\sim 40$ days after resection of the primary tumour. Photodynamic therapy or OV treatment alone delayed progression of metastatic disease in all mice, and led to tumourfree survival in $50 \%$ of animals (Figure $6 \mathrm{~B}, P<0.05$ ). Metastatic lesions developed primarily in the brachial and axillary lymph nodes, and were less frequent in liver, spleen and bone marrow as determined by staining with NXS2-reacting 14G2a mAb or tyrosine hydroxylase-specific RT - PCR (Gil et al, 2009). On the other hand, mice that received combined PDT $\left(128 \mathrm{~J} \mathrm{~cm}^{-2}\right.$ at $\left.14 \mathrm{~mW} \mathrm{~cm}^{-2}\right)$ and OV treatment did not develop metastatic disease by day 50 , and only one out of six mice had recurrent tumour $(P=0.007)$. In summary, the increased survival rate among NXS2 tumour-bearing mice after the combined PDT regimen of $128 \mathrm{~J} \mathrm{~cm}^{-2}$ at $14 \mathrm{~mW} \mathrm{~cm}^{-2}$ and $\mathrm{OV}$ suggests that increases in inratumoural viral replication together with a profound reduction in tumour perfusion associated with the sink effect of activated neutrophils/MDSCs could prevent destabilisation of a premetastatic niche leading to inhibition of the metastatic spread.

\section{DISCUSSION}

Over the years, PDT has been clinically effective as a curative (Rigual et al, 2009) and palliative treatment (Lightdale et al, 1995) for solid tumours. Here, we report, for the first time, the use of PDT to increase the antitumour efficacy of OV.

Engineered OVVs have demonstrated promising results in the treatment of cancer in preclinical models and early clinical trials (Park et al, 2008; Kirn and Thorne, 2009), and it is likely that OV will be combined with other treatments to maximize their effectiveness. Recent reports have demonstrated augmentation of antitumour efficacy of $\mathrm{OV}$ by manipulating vascular endothelial growth factor-mediated signalling (Guse et al, 2010; Kottke et al, 2010). In contrast, our approach involved disruption of tumour vasculature using PDT to enhance viral delivery and 
A

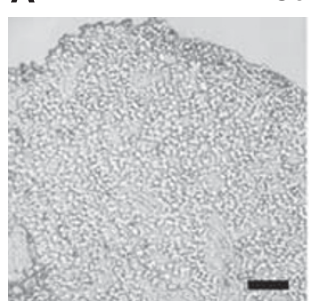

ntrol

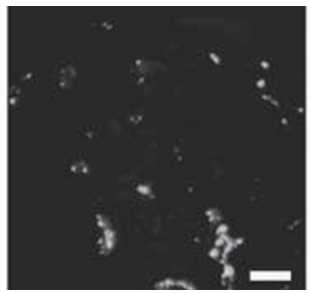

128@14
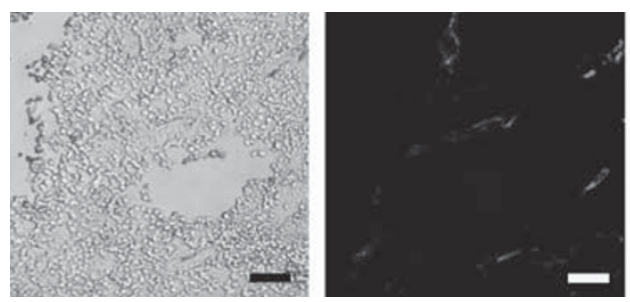

B
Control

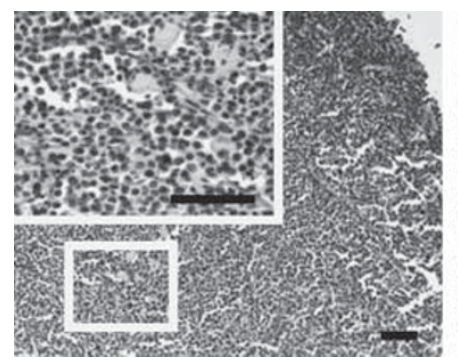

128@14

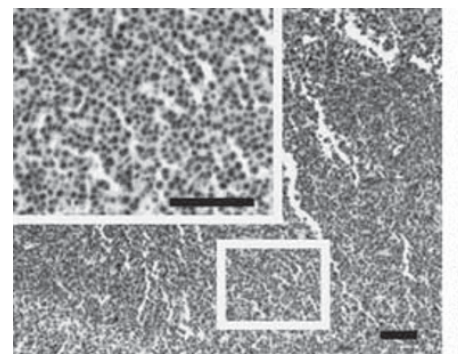

OV

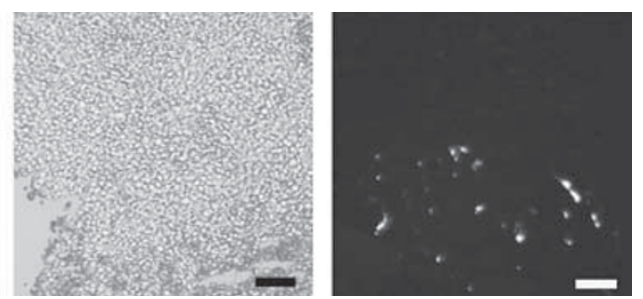

$128 @ 14$ + OV
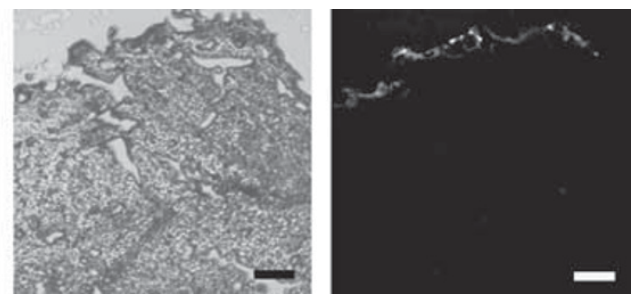

OV

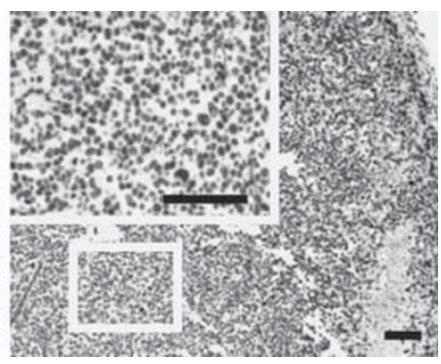

$128 @ 14$ + OV

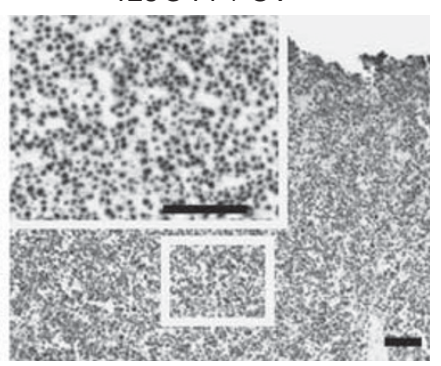

Figure 5 Decreases in blood perfusion within tumours after OV treatment alone or in combination with PDT. (A) A/J mice with NXS2 tumours were treated with PDT $\left(128 \mathrm{~J} \mathrm{~cm}^{-2}\right.$ at $14 \mathrm{~mW} \mathrm{~cm}^{-2}$ ) and/or OVV-EGFP (I0 PFU), perfused with fluorescent microspheres on day 5 after the viral injection, and euthanised $5 \mathrm{~min}$ later. Control tumours derived from mice treated with UV-inactivated OV and HPPH. Three tumours were tested, and data from representative tumours are shown. Scale bars, $100 \mu \mathrm{m}$. (B) Immunohistochemical assessment of the tumour vasculature after treatment with $\mathrm{OVV}$-EGFP and/or PDT $\left(128 \mathrm{~J} \mathrm{~cm}^{-2}\right.$ at $\left.14 \mathrm{~mW} \mathrm{~cm}^{-2}\right)$. Tumours were harvested on day 5 after treatment. Sections of tumours were stained for anti-CD3I antigen, and representative images are shown. Scale bars, $100 \mu \mathrm{m}$.

distribution. The results show increased therapeutic efficacy of vaccinia virus against primary and metastatic tumours when used in combination with PDT.

The effectiveness of PDT is influenced by multiple parameters such as the type of sensitiser, its dose, the interval between sensitiser injection and photoactivation, the incident light dose (fluence) and light dose rate (fluence rate) (Henderson et al, 2004). In our study, maximal antitumour efficacy was observed when the virus was administered $12 \mathrm{~h}$ following PDT and the therapeutic benefit with combination treatment was influenced by the PDT treatment regimen. This is not surprising since the relative contributions of the tumour cellular, vascular and inflammatory responses following PDT are strongly influenced by the choice of illumination scheme or the PDT regimen (Henderson et al, 2004; Seshadri et al, 2005). Results of our MRI studies provide evidence of significant tumour vascular disruption (12-h post PDT) at the time of virus administration. However, this destruction of vascular architecture was not associated with a complete cessation of blood flow within the tumour, suggesting that the PDT-mediated changes in tumour vasculature could enable delivery of oncolytic viruses to tumours resulting in infection/lysis of tumour cells that survived PDT treatment. The changes in tumour vascular permeability might be associated with subtle endothelial injury well below a critical threshold required for complete vascular collapse and shutdown of perfusion. This PDT-mediated vascular destabilisation could be further potentiated by infection with OV that triggers vascular collapse and a loss of blood flow to the interior of the tumour, causing induction of massive cellular death. Several possibilities can be considered for the PDT fluence rate-dependent differences in the antitumour efficacy of the virus. It is likely that the PDT-induced photosensitisation caused endothelial cell microtubule depolarisation and induced formation of actin stress fibres. Changes in the endothelial cell integrity, which are maintained by cytoskeletal components such as filament actin 


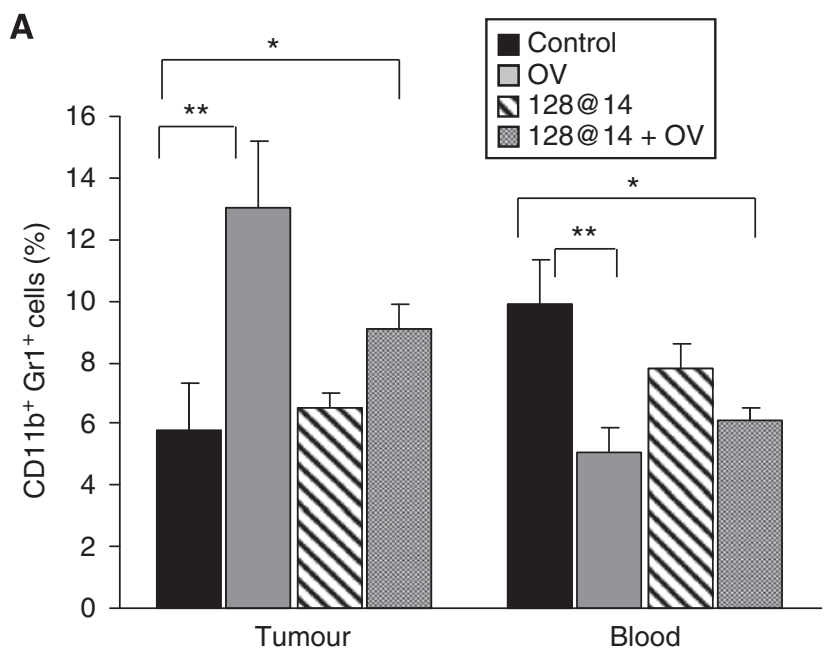

B

Inhibition of NXS2 metastatic disease

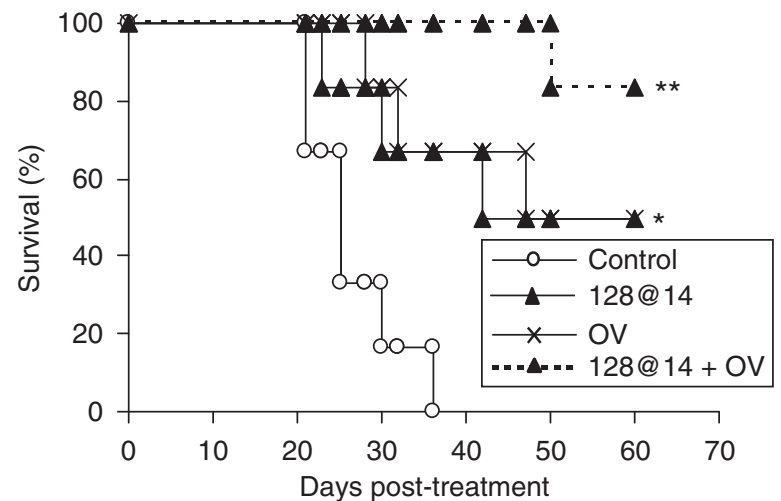

Figure 6 Enhanced recruitment of neutrophils to tumours and inhibition of spontaneous metastasis by OV and PDT treatments. (A) The numbers of $\mathrm{Grl}^{+} \mathrm{CDIIb}^{+}$neutrophils/MDSCs in tumours and the peripheral blood of NXS2-bearing mice $(n=3)$ were determined by mAbs to $\mathrm{Grl}$ and CDIIb followed by flow cytometry 5 days after treatments. (B) NXS2-bearing mice $(n=6)$ with tumour volume of $\sim 200 \mathrm{~mm}^{3}$ underwent PDT and/or OV treatments 7 days before tumour resection. Control mice had primary tumour excised without treatment. Kaplan-Meier survival plots were prepared, and significance was determined using the log rank Mantel-Cox method. $* P<0.05, * * P=0.007$

and microtubules would lead to the formation of intracellular gaps and endothelial barrier dysfunction (Hobbs et al, 1998; Chen et al, 2006). This would have little influence on extravasation of small molecules such as conjugates of albumin, which is about $67 \mathrm{kDa}$ with a diameter of about $7 \mathrm{~nm}$ (Chen et al, 2006) because tumour vessels typically have larger interendothelial junctions than normal blood vessels (Roberts and Palade, 1997). However, it could significantly facilitate the extravasation of larger molecules, such as 2000-kDa dextran estimated to be about $100 \mathrm{~nm}$ (Yuan et al, 2003)

\section{REFERENCES}

Bell E, Shamim M, Whitbeck JC, Sfyroera G, Lambris JD, Isaacs SN (2004) Antibodies against the extracellular enveloped virus B5R protein are mainly responsible for the EEV neutralizing capacity of vaccinia immune globulin. Virology 325: 425-431

Bellnier DA, Greco WR, Loewen GM, Nava H, Oseroff AR, Pandey RK, Tsuchida T, Dougherty TJ (2003) Population pharmacokinetics of the photodynamic therapy agent 2-[1-hexyloxyethyl]-2-devinyl pyropheophorbide-a in cancer patients. Cancer Res 63: 1806-1813

or vaccinia virus estimated for $300 \mathrm{~nm}$ (Lun et al, 2009), which are otherwise difficult to transport across the endothelial barrier.

Taken together, the favourable interaction observed with the PDT and OV combination treatment is likely related to effective targeting of both vascular and cellular components of the tumour. The finding that PDT-treated tumour cells are susceptible to viral infection and replication, indicate that these cells can serve as a source of infectious viral particles available for dissemination throughout the tumour microenvironment. Thus, an effective targeting of multiple components by the combination treatment could explain its efficacy not only in the treatment of the primary tumour, but most importantly, against spontaneous metastasis. The latter effect could be associated with vascular shutdown in the primary tumours that affected migration of the metastatic cells to other organs after a neutrophil-dependent initiation of microclots within tumour blood vessels (Breitbach et al, 2011). Our observation of vascular collapse and infiltration of neutrophils/ MDSCs after treatment with OVV-EGFP is consistent with previous studies in a murine model using VSV (Breitbach et al, 2007). In addition, a profound reduction in tumour perfusion was also observed in some patients with advanced hepatocellular carcinoma following treatment with an oncolytic poxvirus, JX-594 in early phase trials (Liu et al, 2008; Park et al, 2008), suggesting that a better understanding of the direct and indirect mediators of tumour lysis by the combined treatment will help to optimize therapeutic protocols to achieve the best possible outcomes in patients.

In conclusion, our study provides evidence for the safety and efficacy of the combined PDT-OV treatment against murine tumours and human tumour xenografts. By investigating early events following vaccinia virus infection in tumours, we have discovered a novel, targeted mechanism of tumour destruction, requiring the optimal combination of virus infection and changes in tumour vasculature. The evidence that the use of PDT at low fluence rate significantly enhances antitumour efficacy directly by destroying tumour cells and indirectly by augmenting viral load in the tumour tissue, suggests that potential mechanisms of interaction between the two treatment modalities should be considered for further clinical development. It is clear that a better understanding of the direct and indirect mediators of tumour lysis by the combined treatment will help to optimize therapeutic protocols to achieve the best possible outcomes in patients.

\section{ACKNOWLEDGEMENTS}

We are grateful to Bernard Moss, Raulph Reisfeld, Youcef Rustum and David Bartlett for reagents. We thank Paula Pera for assistance with PDT, Noreen Ersing for help with immunohistochemistry, and Hans Minderman and $S$ Turowski for assistance with Imagestream and MRI studies. This work was supported by the National Institutes of Health Grants CA140886 (DK and RP), EB008071 (DK and MJC), CA55791 (RP and YC), the Roswell Park Alliance Foundation (MS) and Comprehensive Cancer Center Support Grant CA16056.
Biel M (2006) Advances in photodynamic therapy for the treatment of head and neck cancers. Lasers Surg Med 38: 349-355

Breitbach CJ, De Silva NS, Falls TJ, Aladl U, Evgin L, Paterson J, Sun YY, Roy DG, Rintoul JL, Daneshmand M, Parato K, Stanford MM, Lichty BD, Fenster A, Kirn D, Atkins H, Bell JC (2011) Targeting tumor vasculature with an oncolytic virus. Mol Ther 19: $886-894$

Breitbach CJ, Paterson JM, Lemay CG, Falls TJ, McGuire A, Parato KA, Stojdl DF, Daneshmand M, Speth K, Kirn D, McCart JA, Atkins H, Bell JC 
(2007) Targeted inflammation during oncolytic virus therapy severely compromises tumor blood flow. Mol Ther 15: 1686-1693

Chen B, Pogue BW, Luna JM, Hardman RL, Hoopes PJ, Hasan T (2006) Tumor vascular permeabilization by vascular-targeting photosensitization: effects, mechanism, and therapeutic implications. Clin Cancer Res 12: $917-923$

DiPaola RS, Plante M, Kaufman H, Petrylak DP, Israeli R, Lattime E, Manson K, Schuetz T (2006) A phase I trial of pox PSA vaccines (PROSTVAC-VF) with B7-1, ICAM-1, and LFA-3 co-stimulatory molecules (TRICOM) in patients with prostate cancer. I Transl Med 4: 1

Gil M, Bieniasz M, Wierzbicki A, Bambach BJ, Rokita H, Kozbor D (2009) Targeting a mimotope vaccine to activating Fcgamma receptors empowers dendritic cells to prime specific CD8 $+\mathrm{T}$ cell responses in tumor-bearing mice. J Immunol 183: 6808-6818

Guo ZS, Thorne SH, Bartlett DL (2008) Oncolytic virotherapy: molecular targets in tumor-selective replication and carrier cell-mediated delivery of oncolytic viruses. Biochim Biophys Acta 1785: 217-231

Guse K, Sloniecka M, Diaconu I, Ottolino-Perry K, Tang N, Ng C, Le Boeuf F, Bell JC, McCart JA, Ristimaki A, Pesonen S, Cerullo V, Hemminki A. (2010) Antiangiogenic arming of an oncolytic vaccinia virus enhances antitumor efficacy in renal cell cancer models. J Virol 84: 856-866

Henderson BW, Gollnick SO, Snyder JW, Busch TM, Kousis PC, Cheney RT, Morgan J (2004) Choice of oxygen-conserving treatment regimen determines the inflammatory response and outcome of photodynamic therapy of tumors. Cancer Res 64: 2120-2126

Hobbs SK, Monsky WL, Yuan F, Roberts WG, Griffith L, Torchilin VP, Jain RK (1998) Regulation of transport pathways in tumor vessels: role of tumor type and microenvironment. Proc Natl Acad Sci USA 95: 4607-4612

Hu JC, Coffin RS, Davis CJ, Graham NJ, Groves N, Guest PJ, Harrington KJ, James ND, Love CA, McNeish I, Medley LC, Michael A, Nutting CM, Pandha HS, Shorrock CA, Simpson J, Steiner J, Steven NM, Wright D, Coombes RC (2006) A phase I study of OncoVEXGM-CSF, a secondgeneration oncolytic herpes simplex virus expressing granulocyte macrophage colony-stimulating factor. Clin Cancer Res 12: 6737-6747

Kick G, Messer G, Goetz A, Plewig G, Kind P (1995) Photodynamic therapy induces expression of interleukin 6 by activation of AP-1 but not NF-kappa B DNA binding. Cancer Res 55: 2373-2379

Kirn DH, Thorne SH (2009) Targeted and armed oncolytic poxviruses: a novel multi-mechanistic therapeutic class for cancer. Nat Rev Cancer 9: $64-71$

Kirn DH, Wang Y, Liang W, Contag CH, Thorne SH (2008) Enhancing poxvirus oncolytic effects through increased spread and immune evasion. Cancer Res 68: 2071-2075

Kottke T, Hall G, Pulido J, Diaz RM, Thompson J, Chong H, Selby P, Coffey M, Pandha H, Chester J, Melcher A, Harrington K, Vile R (2010) Antiangiogenic cancer therapy combined with oncolytic virotherapy leads to regression of established tumors in mice. J Clin Invest 120: 1551- 1560

Lightdale CJ, Heier SK, Marcon NE, McCaughan Jr JS, Gerdes H, Overholt BF, Sivak Jr MV, Stiegmann GV, Nava HR (1995) Photodynamic therapy with porfimer sodium versus thermal ablation therapy with Nd:YAG laser for palliation of esophageal cancer: a multicenter randomized trial. Gastrointestinal Endoscopy 42: 507-512

Liu TC, Hwang T, Park BH, Bell J, Kirn DH (2008) The targeted oncolytic poxvirus JX-594 demonstrates antitumoral, antivascular, and anti-HBV activities in patients with hepatocellular carcinoma. Mol Ther 16: $1637-1642$

Lun XQ, Jang JH, Tang N, Deng H, Head R, Bell JC, Stojdl DF, Nutt CL, Senger DL, Forsyth PA, McCart JA (2009) Efficacy of systemically administered oncolytic vaccinia virotherapy for malignant gliomas is enhanced by combination therapy with rapamycin or cyclophosphamide. Clin Cancer Res 15: 2777-2788

McCart JA, Ward JM, Lee J, Hu Y, Alexander HR, Libutti SK, Moss B, Bartlett DL (2001) Systemic cancer therapy with a tumor-selective vaccinia virus mutant lacking thymidine kinase and vaccinia growth factor genes. Cancer Res 61: 8751-8757

Mitra S, Cassar SE, Niles DJ, Puskas JA, Frelinger JG, Foster TH (2006) Photodynamic therapy mediates the oxygen-independent activation of hypoxia-inducible factor 1alpha. Mol Cancer Ther 5: 3268-3274
Nathan C (2006) Neutrophils and immunity: challenges and opportunities. Nat Rev Immunol 6: 173-182

Neal ZC, Imboden M, Rakhmilevich AL, Kim KM, Hank JA, Surfus J, Dixon JR, Lode HN, Reisfeld RA, Gillies SD, Sondel PM (2004) NXS2 murine neuroblastomas express increased levels of MHC class I antigens upon recurrence following NK-dependent immunotherapy. Cancer Immunol Immunother 53: 41-52

Pandey RK, Bellnier DA, Smith KM, Dougherty TJ (1991) Chlorin and porphyrin derivatives as potential photosensitizers in photodynamic therapy. Photochem Photobiol 53: 65-72

Park BH, Hwang T, Liu TC, Sze DY, Kim JS, Kwon HC, Oh SY, Han SY, Yoon JH, Hong SH, Moon A, Speth K, Park C, Ahn YJ, Daneshmand M, Rhee BG, Pinedo HM, Bell JC, Kirn DH (2008) Use of a targeted oncolytic poxvirus, JX-594, in patients with refractory primary or metastatic liver cancer: a phase I trial. Lancet Oncol 9: 533-542

Rigual NR, Thankappan K, Cooper M, Sullivan MA, Dougherty T, Popat SR, Loree TR, Biel MA, Henderson B (2009) Photodynamic therapy for head and neck dysplasia and cancer. Arch Otolaryngol Head Neck Surg 135: $784-788$

Roberts WG, Palade GE (1997) Neovasculature induced by vascular endothelial growth factor is fenestrated. Cancer Res 57: 765-772

Seshadri M, Bellnier DA, Cheney RT (2008) Assessment of the early effects of 5,6-dimethylxanthenone-4-acetic acid using macromolecular contrast media-enhanced magnetic resonance imaging: ectopic versus orthotopic tumors. Int J Radiat Oncol Biol Phys 72: 1198-1207

Seshadri M, Spernyak JA, Mazurchuk R, Camacho SH, Oseroff AR, Cheney RT, Bellnier DA (2005) Tumor vascular response to photodynamic therapy and the antivascular agent 5,6-dimethylxanthenone-4acetic acid: implications for combination therapy. Clin Cancer Res 11: $4241-4250$

Small EJ, Carducci MA, Burke JM, Rodriguez R, Fong L, van Ummersen L, Yu DC, Aimi J, Ando D, Working P, Kirn D, Wilding G (2006) A phase I trial of intravenous CG7870, a replication-selective, prostate-specific antigen-targeted oncolytic adenovirus, for the treatment of hormone-refractory, metastatic prostate cancer. Mol Ther 14: $107-117$

Thorne SH, Hwang TH, O'Gorman WE, Bartlett DL, Sei S, Kanji F, Brown C, Werier J, Cho JH, Lee DE, Wang Y, Bell J, Kirn DH (2007) Rational strain selection and engineering creates a broad-spectrum, systemically effective oncolytic poxvirus, JX-963. J Clin Invest 117: $3350-3358$

Vanderplasschen A, Hollinshead M, Smith GL (1997) Antibodies against vaccinia virus do not neutralize extracellular enveloped virus but prevent virus release from infected cells and comet formation. J Gen Virol 78(Pt 8): $2041-2048$

Vanderplasschen A, Mathew E, Hollinshead M, Sim RB, Smith GL (1998) Extracellular enveloped vaccinia virus is resistant to complement because of incorporation of host complement control proteins into its envelope. Proc Natl Acad Sci USA 95: 7544-7549

Wild PJ, Krieg RC, Seidl J, Stoehr R, Reher K, Hofmann C, Louhelainen J, Rosenthal A, Hartmann A, Pilarsky C, Bosserhoff AK, Knuechel R (2005) RNA expression profiling of normal and tumor cells following photodynamic therapy with 5 -aminolevulinic acid-induced protoporphyrin IX in vitro. Mol Cancer Ther 4: 516-528

Yan HH, Pickup M, Pang Y, Gorska AE, Li Z, Chytil A, Geng Y, Gray JW, Moses HL, Yang L (2010) Gr-1+CD11b+ myeloid cells tip the balance of immune protection to tumor promotion in the premetastatic lung. Cancer Res 70: 6139-6149

Yuan H, Gaber MW, McColgan T, Naimark MD, Kiani MF, Merchant TE (2003) Radiation-induced permeability and leukocyte adhesion in the rat blood-brain barrier: modulation with anti-ICAM-1 antibodies. Brain Res 969: $59-69$

(c) (1) (2) This work is licensed under the Creative Commons cc. BY NC SA Attribution-NonCommercial-Share Alike 3.0 Unported License. To view a copy of this license, visit http://creativecommons. org/licenses/by-nc-sa/3.0/ 